\title{
A CONCEPTUAL SNAPSOT OF A BIG COASTAL DUNE AQUIFER: MAGILLIGAN, NORTHERN IRELAND
}

\author{
N. S. Robins \\ British Geological Survey, Maclean Building, Wallingford OX10 8BB, UK \\ P. Wilson
}

British Geological Survey, Dundonald House, Upper Newtownards Road, Belfast, BT4 3SB

\begin{abstract}
The Magilligan sand spit dune field is situated on the eastern mouth of Lough Foyle in County Londonderry, Northern Ireland. It is a large triangular-shaped site some 7 $\mathrm{km}$ by $4 \mathrm{~km}$ by $1.5 \mathrm{~km}$ wide (about 800 hectares) and maintains areas, particularly in the eastern part, with slacks that regularly flood in winter. The size of the system acts as a buffer to external drivers due to the large volume of groundwater stored, the longer travel distances and lower hydraulic gradients. However, unlike many other coastal dune sites with humid dune slacks in the British Isles the sand is not wholly underlain by silt and clay, as raised beach sand and gravel deposits are in contact with the sand aquifer in some places. A preliminary water balance suggests that the majority of the discharge from the sand aquifer occurs via the underlying raised beach deposits and only a small amount discharges directly from the sand aquifer beneath the foredunes. Available water level monitoring is skewed towards the wetter end of the dune system; no significant short-term water level trends are apparent. The data also indicate that recharge regularly takes place within the sand aquifer interspersed by periods of groundwater level recession.
\end{abstract}

KEYWORDS Sand dune. Groundwater. Water budget. Dune slack.

\section{INTRODUCTION}

Coastal dune wetlands are widely distributed along the Atlantic, North Sea and Baltic coasts (Doody 2008). They comprise open mobile sand and mature vegetated static dunes. The elevation of the water table within the dunes dictates the morphology of the dune fields and determines the elevation at which wetland dune slacks, the flat-floored depressions that occur within the sand dunes, are formed (Stuyfzand 1993). Humid dune slacks, as defined in the EU Habitats Directive, might have a water table $<0.5$ below the slack floor in summer and may be flooded during part of the winter. An alkaline environment promotes a rich and diverse assemblage of basiphilous vegetation. A conceptual understanding of the factors controlling the hydrological regime in dune systems is, therefore, fundamental to successful conservation management, as directed by the EU Habitats Directive, to enable prediction of likely future impacts on the dune system ecology.

Magilligan is the largest coastal dune system in the United Kingdom and Ireland with an area of about 800 hectares. It is a spit system at the eastern end of Lough Foyle in County 
Londonderry (Figure 1). The Magilligan Dunes are located on the end of a cuspate foreland. The underlying estuarine clays, and raised beach sands and gravels result from Holocene sea level decline (Carter 1982). The bedrock lithologies beneath the sand have a complex and as yet partly unknown distribution. The system is currently prograding (NIEA 2010) due to the convergence of the Atlantic waves and Lough Foyle waves (Carter 1986). The main foredune faces north onto Magilligan Strand, a $7 \mathrm{~km}$ length of gently sloping beach. The dunes are up to $1.5 \mathrm{~km}$ wide and the west-facing Foyle estuary coast has a $4 \mathrm{~km}$ length of dunes. The dunes have a typical psammosere zonation (Doody 2008) resulting in initial embryo dunes through to scrub and are designated as a Special Area of Conservation (SAC). The highest dunes are up to $7 \mathrm{~m}$ above Ordnance Datum. The dunes overlie raised beach sand and gravel as well as estuarine clay and peat to form a large spit at the base of a basalt scarp on top of chalk which in turn overlies Mercia Mudstone. The Mercia Mudstone outcrops to the seaward side of the scarp, concealed only by unconsolidated Holocene sands and clays.

The sand is generally about $20 \mathrm{~m}$ thick. Exceptionally a borehole in the north west corner of the spit penetrated $25 \mathrm{~m}$ sand over $30 \mathrm{~m}$ of raised beach sands and gravels and glacial and estuarine clays and gravels (borehole record held at GSNI, Belfast). The estuarine clays have been dated at 7600 years BP implying that the overlying aeolian sands are considerably younger (Carter 1975). The superficial strata rest on Mercia Mudstone Group rocks, neither the basalt nor the chalk outcropping north west of the base of the basalt scarp. Up to $98 \mathrm{~m}$ of Holocene material has been proven on Magilligan Plain behind the dune field. The aeolian sands are medium- to fine-grained, are $90 \%$ quartz and $8 \%$ calcium carbonate (shell debris) with subordinate heavy minerals, mainly magnetite, epidote and biotite (Carter 1975). The sand varies in colour from pale brown to grey. Up to $0.2 \mathrm{~m}$ of sandy and fibrous peaty topsoil is present on the slack floors.

Water flows off the basalt scarp onto the sands. The sands back onto estuarine flats which are extensively drained. However, the relatively poor transmissive properties of the alluvial strata do not allow groundwater to flow inland into these deposits. There is a main drainage ditch along the dunes and flats divide; this acts as a near constant head feature although little flow is observed in the ditch even when the site is exceptionally wet. No runoff appears to take place other than along a narrow ditch at the foot of the basalt scarp flowing directly to the sea. The sand deposits, therefore, receive only direct rainfall recharge over their full areal extent, no overland flow or groundwater throughflow is likely either from the basalt/chalk scarp or from the alluvial plain to the east.

Chemically, the groundwater within the sand is of the $\mathrm{Ca}-\mathrm{HCO}_{3}$ type reflecting the abundance of shell debris. The $\mathrm{pH}$ ranges from 7.5 to 8.0, while $\mathrm{HCO}_{3}<300 \mathrm{mg} / \mathrm{l}$ and $\mathrm{Cl}$ ranges from 30 to $40 \mathrm{mg} / \mathrm{l}$ reflecting the maritime environment of the spit.

There are up to seven years of transducer-derived hydrograph data recorded at 1 hour intervals from ten shallow dipwells open to the sand at their base. A total of 14 dipwells are sited for best coverage of a control area situated between a large Ministry of Defence training centre and a caravan park rather than distributed formally about the dune system or along a 
transect (Figures 2 and 3). They are all situated in slacks where the water table is shallow, none on the adjacent ridges where deeper wells would be needed to access the water table.

The part of the dune system used by the Ministry of Defence has restricted public access. Military activity may have both a negative impact on fauna and a positive impact where activity tends to help remobilise the sand. There is a risk of nutrient contamination from the caravan park and from grassland farming which encroaches onto the sand.

Magilligan is protected in that there is no public access to much of the dune system. Like other military protected dune zones, such as Pendine in South Wales, it is assumed that the site is as near pristine as possible given natural impacts of dry $\mathrm{N}$ deposition and the impact of marine aerosols. Scale has a direct impact on dune status and dune stability because larger sites are better protected against change than smaller ones. This is largely a response to the greater volumes of groundwater stored in the larger sites, longer transport distances and consequent lower hydraulic gradients towards the peripheral discharge zones from the dune system. This concept of relative stability can be demonstrated at Magilligan, a stable site compared to conditions at smaller dune spit systems that also have limited management.

The relative hydraulic stability at the larger sites has a direct bearing on the ecohydrology of such dune systems with implications that suggest a need for light-touch conservation management only. Species of ecological importance that occur at Magilligan, for example, include rare plants such as smooth cat's ear (Hypochoeris glabra) and hoary whitlow grass (Draba incana) as well as the bee orchid (Ophrys apifera) and marsh helleborine (Epipactis palustris.). Magilligan is the only known site in Ireland which supports Rhytidium rugosum (NIEA 2010).

\section{COASTAL DUNE SCALE AND WATER TABLE ELEVATION}

Most coastal dunes in the British Isles are shallow rain-fed aquifers draining to the periphery of the dune system; to the foredunes and the beach and inland to low-lying land. They are generally underlain by estuarine or glacial clays which form a distinct weakly permeable hydraulic base to the aquifer, i.e. most dune sands are in poor hydraulic continuity with bedrock (Stratford et al. 2013). The groundwater dome within the dune system is controlled by the physical properties of the sand aquifer, the areal dimensions of the dune system and effective precipitation. Each coastal dune system has its own unique features but there are nevertheless common features between all of them (Stratford et al. 2013, Robins et al. 2013). Therefore, the sensitivities of each system may differ, one site might be susceptible to changes in vegetation, another to coastal erosion and accretion, while a third is sensitive to the rainfall regime. In all these systems the ecohydrological status is linked directly to dune hydrogeology (Davy et al. 2006).

There is a distinct relationship between the overall size of a dune system and the elevation of the water table within it. Robins et al. (2013) investigated this relationship using observed 
data from Whiteford Burrows on the Gower Peninsula in South Wales. Whiteford Burrows is $4 \mathrm{~km}$ in length and up to $1 \mathrm{~km}$ broad backing onto estuarine mud flats. On 17 March $1995 \mathrm{a}$ severe late winter storm event caused extensive erosion of the foredune, reducing the effective width of the dune system by $40 \mathrm{~m}$, i.e. by $4 \%$. This caused a rapid decline in the water table elevation by up to $1 \mathrm{~m}$, notably during the ensuing summer months (Figure 4). This dune system drains both to sea beneath the foredune and inland onto estuarine flats so that the average maximum travel distance or groundwater flowpath length is just $0.5 \mathrm{~km}$, half the width of the dune system. At Magilligan it drains in one direction only, to the foredune discharge area, and the average flowpath is $1.5 \mathrm{~km}$ long, three times the length of those at Whiteford Burrows.

The Whiteford Burrows example illustrates the relationship between scale of a dune system and the elevation of the water table in a single dune system. However, the relationship is transferable to other sites given that both formation hydraulic conductivity (permeability) and recharge directly control flow rates according to the relationship defined by Henry (1964):

$$
\mathrm{h}^{2}=\mathrm{c} \cdot \mathrm{b}^{2}
$$

where:

$h$ is the height or elevation above mean sea level of the water table ridge in the dune system

$\mathrm{b}$ is the breadth of the spit, and

c is a constant, a function of transmissivity and recharge,

The important aspect of the Henry formula, illustrated at Whiteford Burrows, is that $\mathrm{h}$ and $\mathrm{b}$ have a linear relationship for any given site. It also indicates that the larger the dune system, the higher the potential water table elevation. The corollary to this, of course, is that the higher the water table elevation, the greater the potential for dune slacks to be termed as humid dune slacks, according to the EU Habitats Directive, where the features could be classified as favourable. Thus a short flowpath site such as Whiteford Burrows is essentially unstable and vulnerable to external influences whereas the longer flowpaths at Magilligan tend to buffer these same influences.

The relatively high elevation water table causes many of the dune slacks at Magilligan to flood during the winter months while standing water is present at some locations throughout the year. The slack at dipwell 10, for example, was monitored during the period September 2009 and July 2010 and was flooded or partially flooded up to a maximum depth of $0.25 \mathrm{~m}$ for $25 \%$ of this time (Ray Flynn personal communication). Other slacks have a similar flooding profile. Nevertheless these features are not classified as favourable (EU Habitats Directive) in terms of the ecology they support.

Due to the prevailing westerly winds, Magilligan benefits from a high annual average rainfall (1107 mm) and moderate evapotranspiration $(527 \mathrm{~mm})$ which encourage recharge to the sand aquifer (long term data for Malin Head, Met Éireann). The response of groundwater levels to rainfall reflects a dynamic actively recharged system (Figure 5). Rapid rises in groundwater 
head following rainfall occur in winter time and early spring, and contrast with a less sensitive response to rainfall in the later spring and summer months. This suggests that evapotranspiration may generate a moisture deficit in the unsaturated zone overlying the water table during the summer and early autumn months. However, the overriding trend is one of receding water levels during these months so that recharge has to exceed the receding water level rate to effect a positive change in the water table elevation. This causes either a delayed summer recharge response or no response at all.

The sand is well sorted and appears to be of consistent grain size with a median value of 0.2 $\mathrm{mm}$ and $\mathrm{d}_{10}$ of $0.15 \mathrm{~mm}$ (NI CPD 2008). Hazen analysis of permeability (Hazen 1893) indicates a conductivity value of about $1 \times 10^{-4} \mathrm{~m} / \mathrm{s}$. The measured groundwater gradient towards the coast through the monitoring dipwells is approximately 0.004 and continues south to the intersection between the sand and the clay ad silt deposits inland indicating that the sands are self-draining with no flow passing inland. At low tide the foreshore along Magilligan Strand is wet with a brackish mixture of sea water and fresh groundwater discharging to surface (Figure 6). A Darcian slice calculation indicates that the potential throughflow per metre width of beach is given by:

$$
\mathrm{q}=\mathrm{kh} \mathrm{dh} / \mathrm{dx}=0.0001 \times 20 \times 0.004=0.000008 \mathrm{~m}^{3} \text { sec or nearly } 0.7 \mathrm{~m}^{3} \text { per day per } \mathrm{m}
$$

Where $\mathrm{q}$ is the throughflow per unit width of the aquifer, $\mathrm{k}$ is the permeability and $\mathrm{dh} / \mathrm{dx}$ is the prevailing hydraulic gradient to the discharge zone. Given that the likely active hydraulic front of the dune system is only about $4 \mathrm{~km}$, along which length the foreshore is wet at low tide, this equates to $2800 \mathrm{~m}^{3}$ of water coming off the site beneath the foredunes each day. As the triangular area of the dune system is $7 \mathrm{~km}$ by $4 \mathrm{~km}$ by $1.5 \mathrm{~km}$, this runoff equates to a recharge of $2.7 \times 10^{-4} \mathrm{~m} / \mathrm{day} / \mathrm{m}^{2}$ or $8 \mathrm{~mm} /$ year equivalent depth of rainfall). Long term average rainfall is just over $1000 \mathrm{~mm}$ per year so if $527 \mathrm{~mm}$ is lost to transpiration an expected depth of $473 \mathrm{~mm}$ per year would seem realistic. However, the Darcian slice calculation equivalent depth of recharge of just $8 \mathrm{~mm} /$ year is two orders of magnitude less than the areal recharge estimate.

Flow inland is prevented by the Basalt scarp and flow west towards the Foyle Estuary is prevented by the clays within the marine alluvium; so where is the recharging groundwater discharging to in order to maintain long term water table equilibrium? The probable answer is that it discharges into the underlying raised beach deposits and glacial gravels, where they are exposed by the estuarine clays beneath the sand, and that it is transmitted to discharge directly into the sea within this stratum. Thus if the combined sand dune and raised beach aquifer is $50 \mathrm{~m}$ thick and the effective permeability is at the upper range of $0.5 \mathrm{~m} / \mathrm{s}$ the same calculation provides an equivalent depth of discharge of $530 \mathrm{~mm} /$ year, i.e. a much more plausible estimate compared to the prevailing effective rainfall. However, it should be noted that the sub-surface confirmation of the estuarine clays and of the raised beach deposits is not yet known, and these calculations offer only a preliminary explanation to the water budget in the dune sand aquifer. 
At first sight Magilligan appears to be a large dune system that is well buffered from external impacts. On closer inspection it is apparent that the monitoring sites are situated in an area of highest water table elevation whereas the dune system to the north is lower-lying with lower water table elevations. The available groundwater level data are, therefore, skewed and reflect a higher than average and an altogether wetter dune system than is actually the case throughout the whole site. A conceptual water balance for the dune system, there being no significant observed runoff, is:

Rainfall - evapotranspiration $=$ runoff + recharge $=$ discharge out of the sand aquifer

Preliminary numbers to this equation suggest (mm equivalent depth of rainfall):

$1100-527=573=0+573=573$

Of the $573 \mathrm{~mm}$ recharge/discharge balance of a hydraulic system at equilibrium, all but a small part is transported through the underlying raised beach and glacial sands and gravels, none discharges inland and only a limited portion passes beneath the foredune within the sand aquifer to the sea. The raised beach deposits are best developed in the central and western part of the system, i.e. to the west of the monitoring site. The raised beach material is partly concealed by estuarine alluvium. However, the raised beach sand and gravel deposits are in contact with the sand locally sufficient to allow the drainage of the sand aquifer to a submarine outlet. The head difference between the water in the sand aquifer and the discharge elevation from the sand and gravel aquifer is small; the base level is sea level for the composite aquifer. Thus although the majority of the discharge takes place through the higher permeabilty sand and gravel, the formation permeability and the prevailing hydraulic gradient in the overall hydraulic system conspire to maintain the hydraulic equilibrium.

The whole dune system now appears to be hydraulically more complex than the initial 'big is beautiful concept' initially suggested. It is also apparent that considerable exploratory work needs to be undertaken to begin to take this initial conceptualisation to a point that it can start to help the hydroecological management of the Magilligan dune system.

\section{CONCLUSIONS}

The preliminary evaluation of the water balance in the Magilligan coastal dune sand aquifer suggests a complex groundwater flow pattern, with the sand in partial hydraulic continuity with the underlying raised beach sands and gravels. Preliminary monitoring of water levels towards the landward southern end of the dune system suggests a favourably high water table and winter flooding of slack floors. To the west the dunes are drier and the slacks flood only intermittently. This distribution reflects the local hydraulic contact with the higher conductivity raised beach material probably only in the northern part of the site, which is taking the vast majority of the discharge away from that part of the site. It also reflects the narrowing width of the dunes towards the northern point of the system. The hydraulic balance is currently at equilibrium although the monitoring period is as yet insufficient to identify any long-term water table elevation trends. 
Considerable investigatory work needs to be carried out throughout the whole dune area in order to better understand the hydraulics of the sand aquifer and the underlying raised beach aquifer. This can best be initiated by extending the monitoring network to include an east west transect across the whole site and at least one north south transect $1 \mathrm{~km}$ west of the present monitoring array. Geophysics may be helpful in assessing where the estuarine clays are present and where the sands and gravels are exposed and what thicknesses are involved. Only with these further data can understanding be advanced in order to underpin any conservation management proposals.

\section{REFERENCES}

Carter RWG (1975) Recent changes in the coastal geomorphology of the Magilligan Foreland, Co. Londonderry. Royal Irish Academy, Chemical Science 75:469-497

Carter RWG (1982) Sea Level Changes in Northern Ireland. Proceedings of the Geologists' Association 93:7-23

Carter RWG (1986) The morphodynamics of beach-ridge formation: Magilligan, Northern Ireland Marine. Geology 73:191-214

Davy AJ, Grootjans AP, Hiscock K, Petersen J (2006) Development of Eco-hydrological Guidelines for Dune Habitats - Phase 1. English Nature Reports, Number 696, Peterborough

Doody JP (ed.) (2008) Sand dune inventory of Europe, $2^{\text {nd }}$ edition. National Coastal Consultants and EUCC - The Coastal Union, in association with the IGU Coastal Commission, Peterborough

Hazen A (1893) Some physical properties of sands and gravels. $24^{\text {th }}$ Annual Report Massachusetts State Board of Health

Henry HR (1964) Effects of dispersion of salt encroachment in coastal aquifers. In Cooper HH, Kohout,FA, Henry HR, Glover RE (eds) Seawater in coastal aquifers. US Geological Survey Water Supply Paper 1613-C:70-83

NIEA (2010) Magilligan Lowlands Geodiversity Profile: Outline geomorphology and landscape setting.

http://www.doeni.gov.uk/niea/landhome/landscape_home/country_landscape/35/35-geo.htm (accessed 23/03/15)

NI CPD (2008) Groundwater Dependent Terrestrial Ecosystem Magilligan (drilling report). NI Central Procurement Directorate Geotechnical Report S10815

Robins NS, Pye K, Wallace H (2013) Dynamic coastal dune spit: the impact of morphological change on dune slacks at Whiteford Burrows, South Wales, UK. Journal of Coastal Conservation 17:473-482 
Stratford C, Robins NS, Clarke D, Jones M. Weaver G (2013). An ecohydrological review of dune slacks on the west coast of England and Wales. Ecohydrology 6(1):162-171

Stuyfzand PJ (1993) Hydrochemistry and hydrology of the coastal dune area of the western Netherlands. Published PhD thesis, Vrije Universieit Amsterdam 
FIGURES

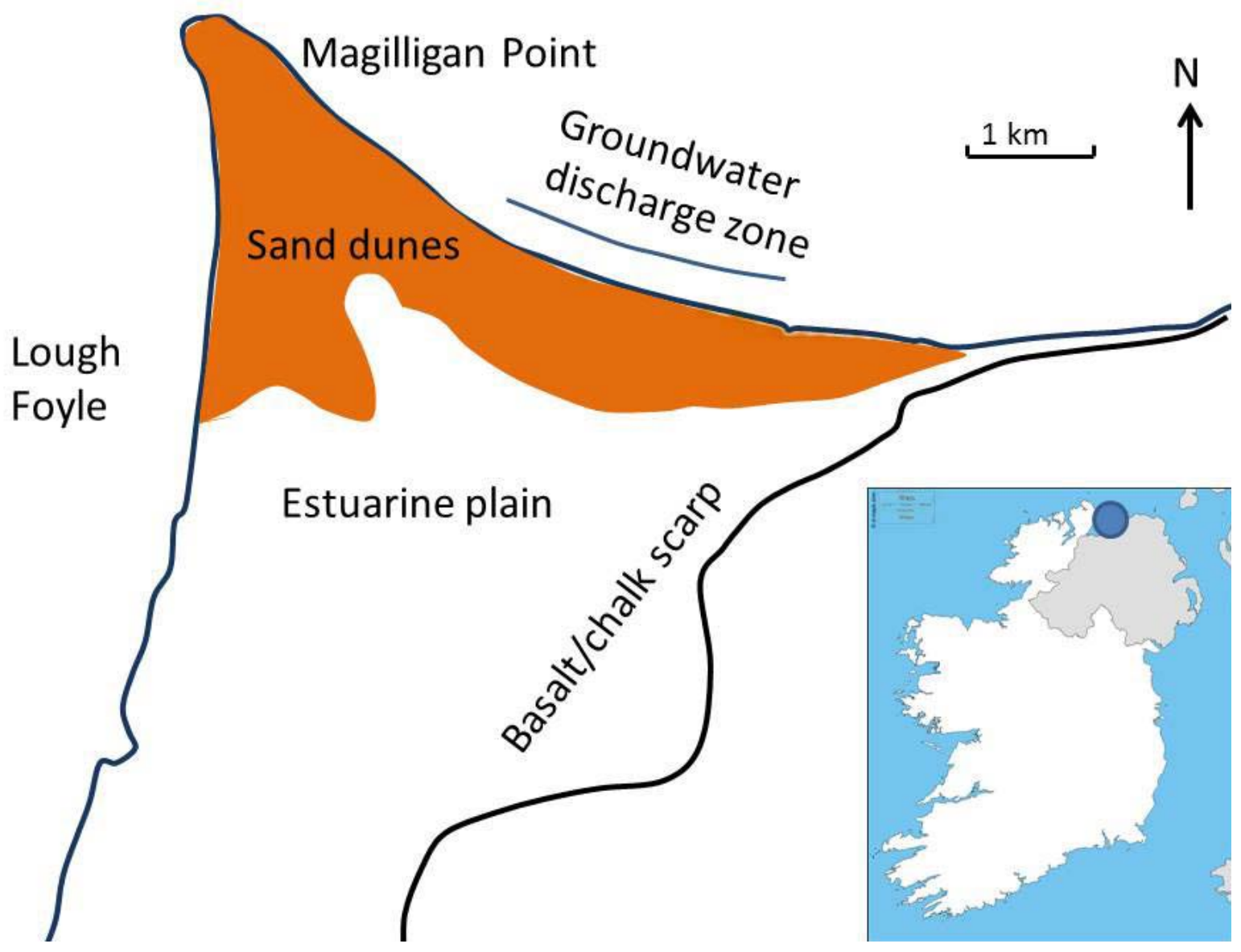

1. Schematic diagram of the Magilligan Dune Spit showing the key features. The sand extends inland beyond the dune area in places with a feather edge over the estuarine plain. Site location (blue circle) is shown in the inset map. 


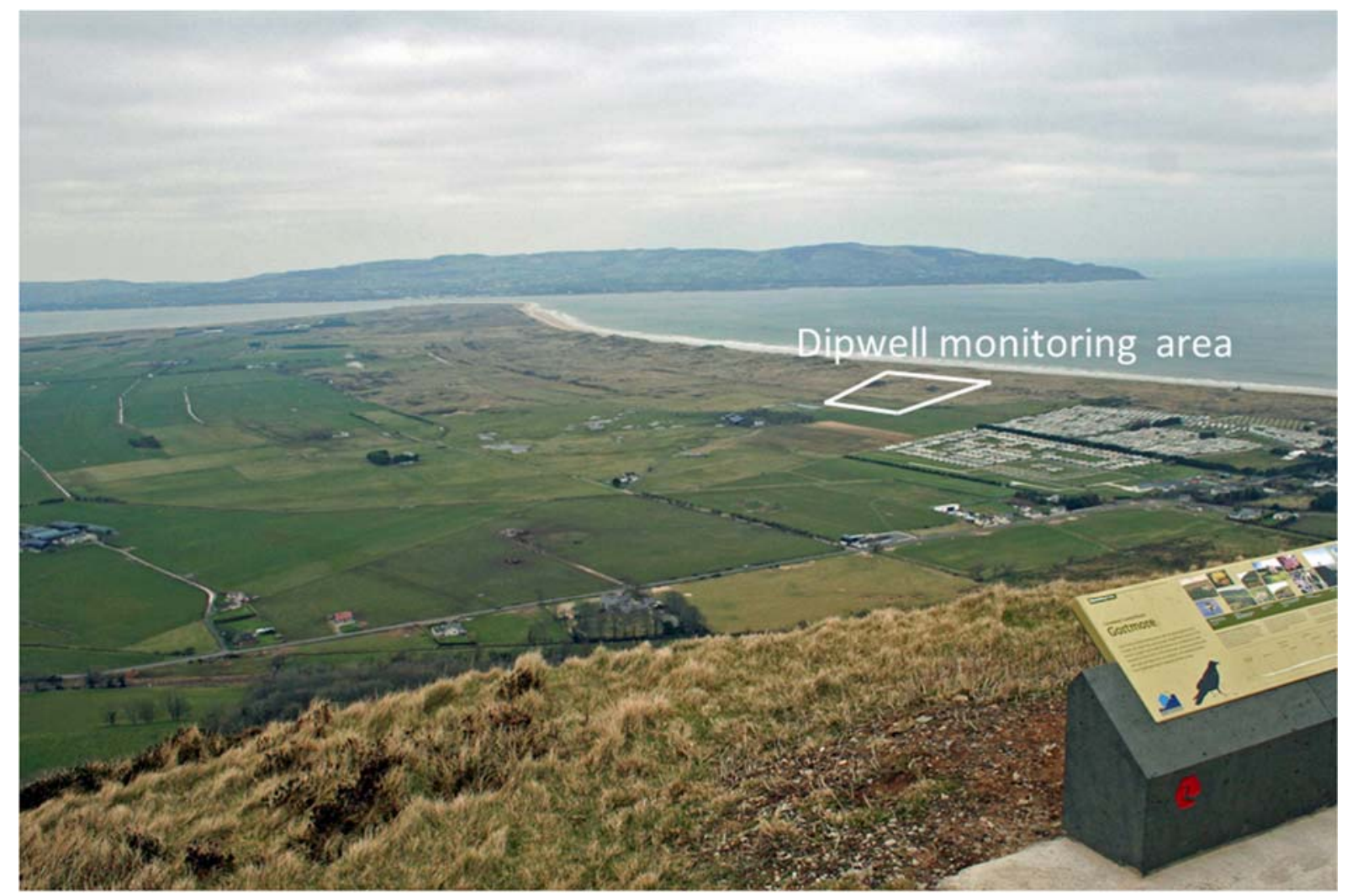

2. The Magilligan dune system seen from the basalt/chalk bluff overlying the site, showing the water level monitoring area. 


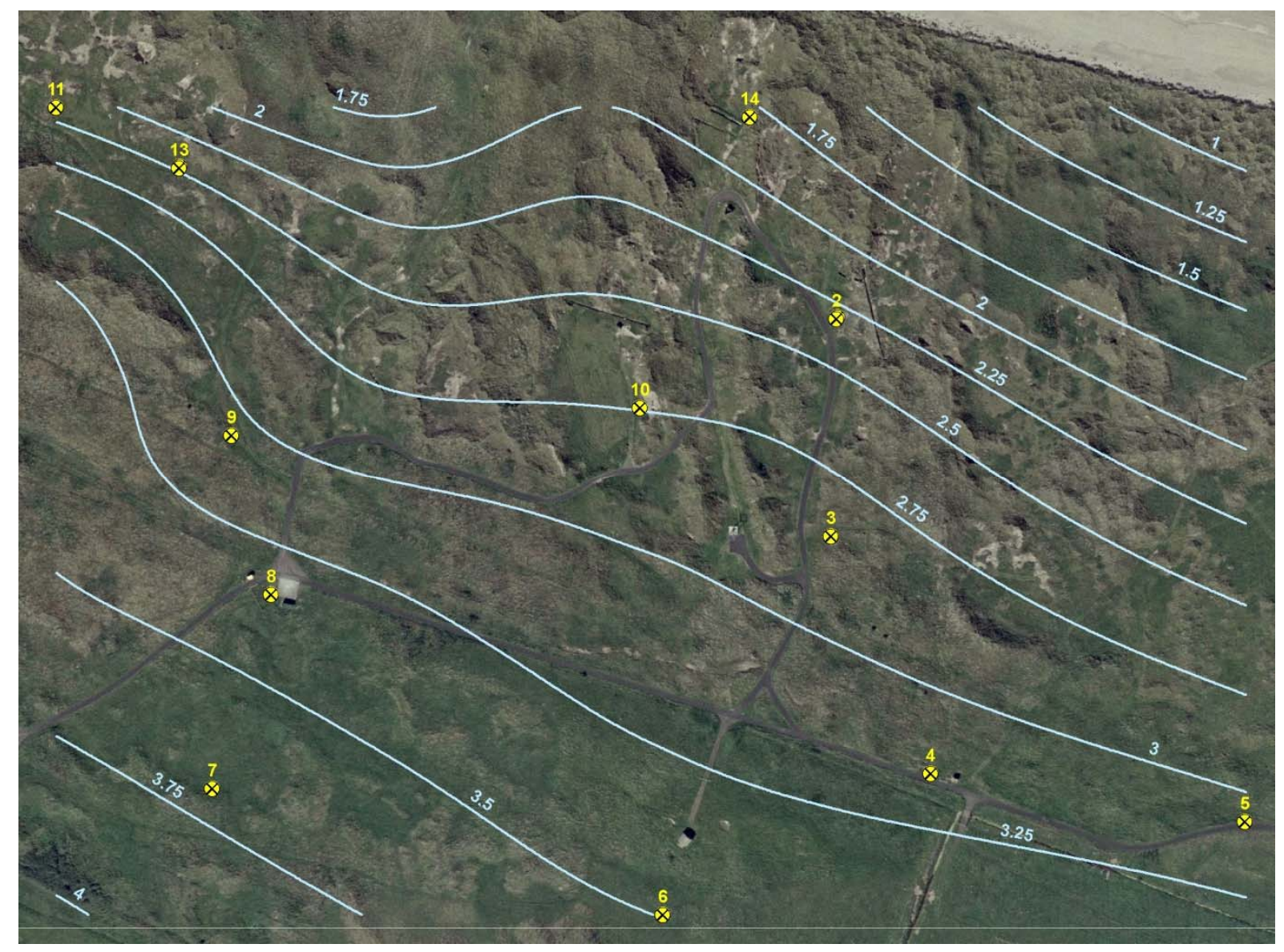

3. The distribution of dipwells looking due north and average water elevations (aOD). The distance from the dipwell nearest the foredunes (14) and the furthest inland dipwell (No. 7) is $510 \mathrm{~m}$. 


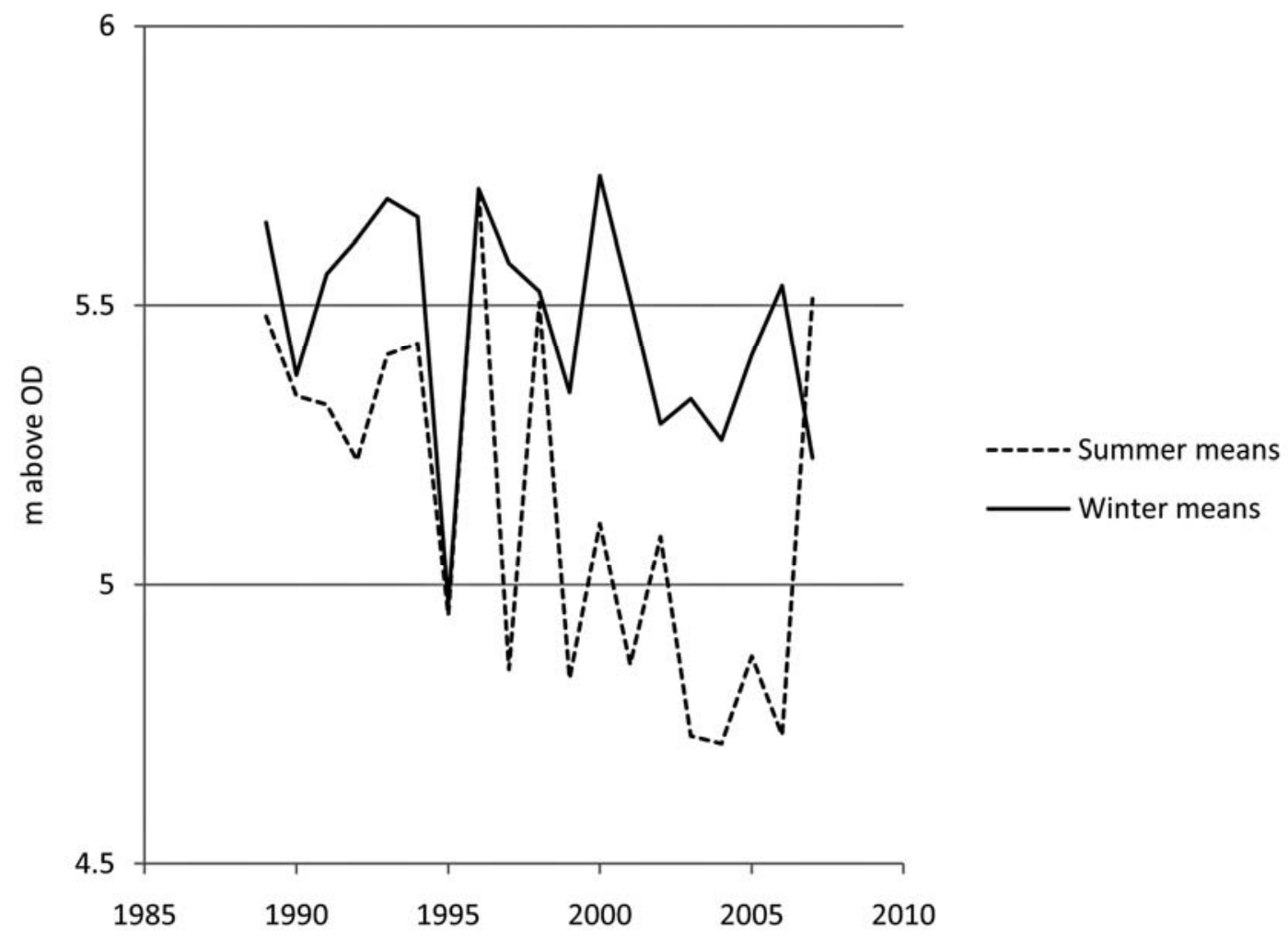

4. Summer and winter average water levels for a dip well at Whiteford Burrows, showing the reduction in summer water levels post foreshore erosion event in 1996 (after Robins et al. 2013). 


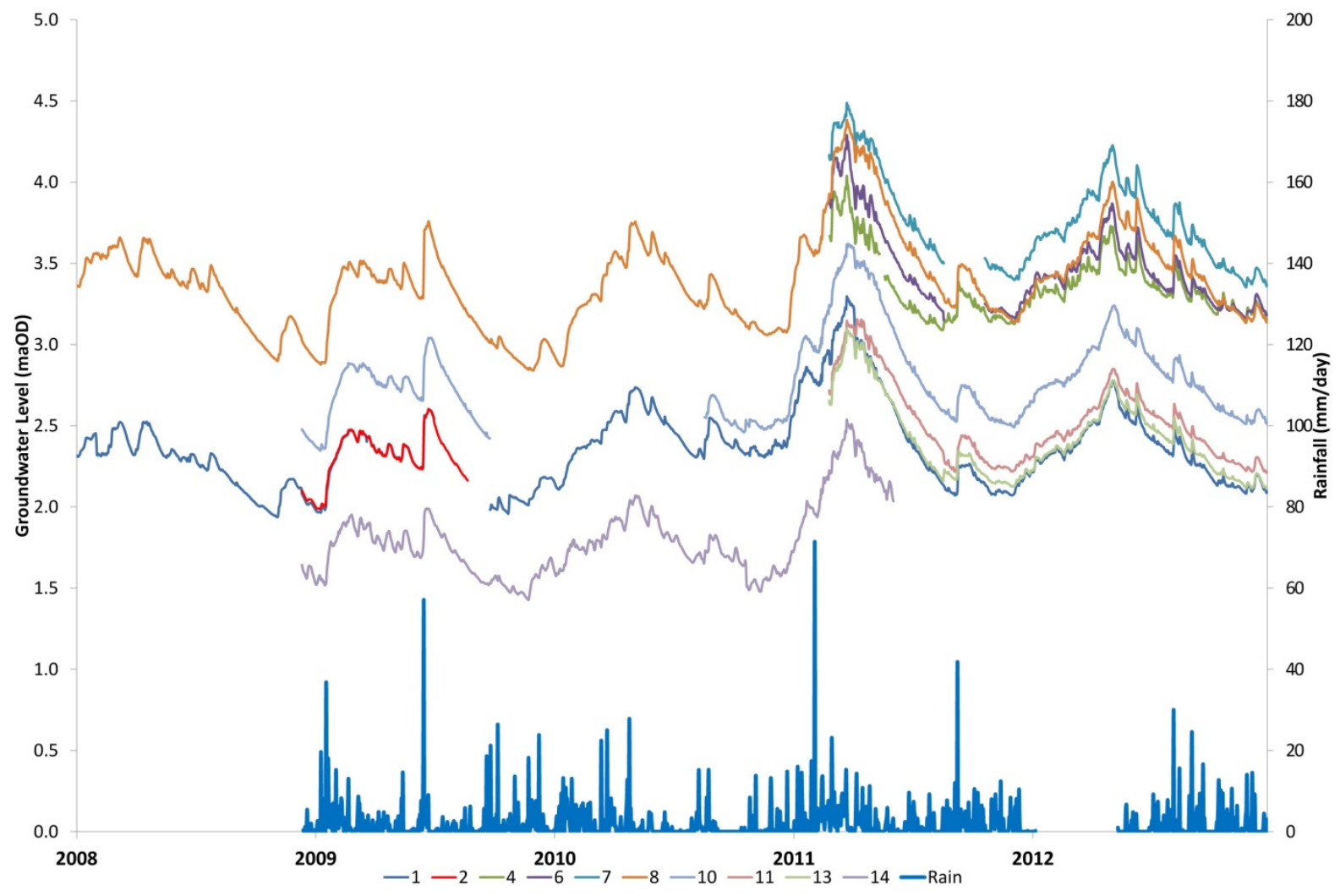

5. Groundwater elevation and rainfall recorded at Magilligan. Water levels respond almost immediately to rainfall events in the winter months but there is an increasing lag in response as the summer months progress, sometimes with no response at all. 


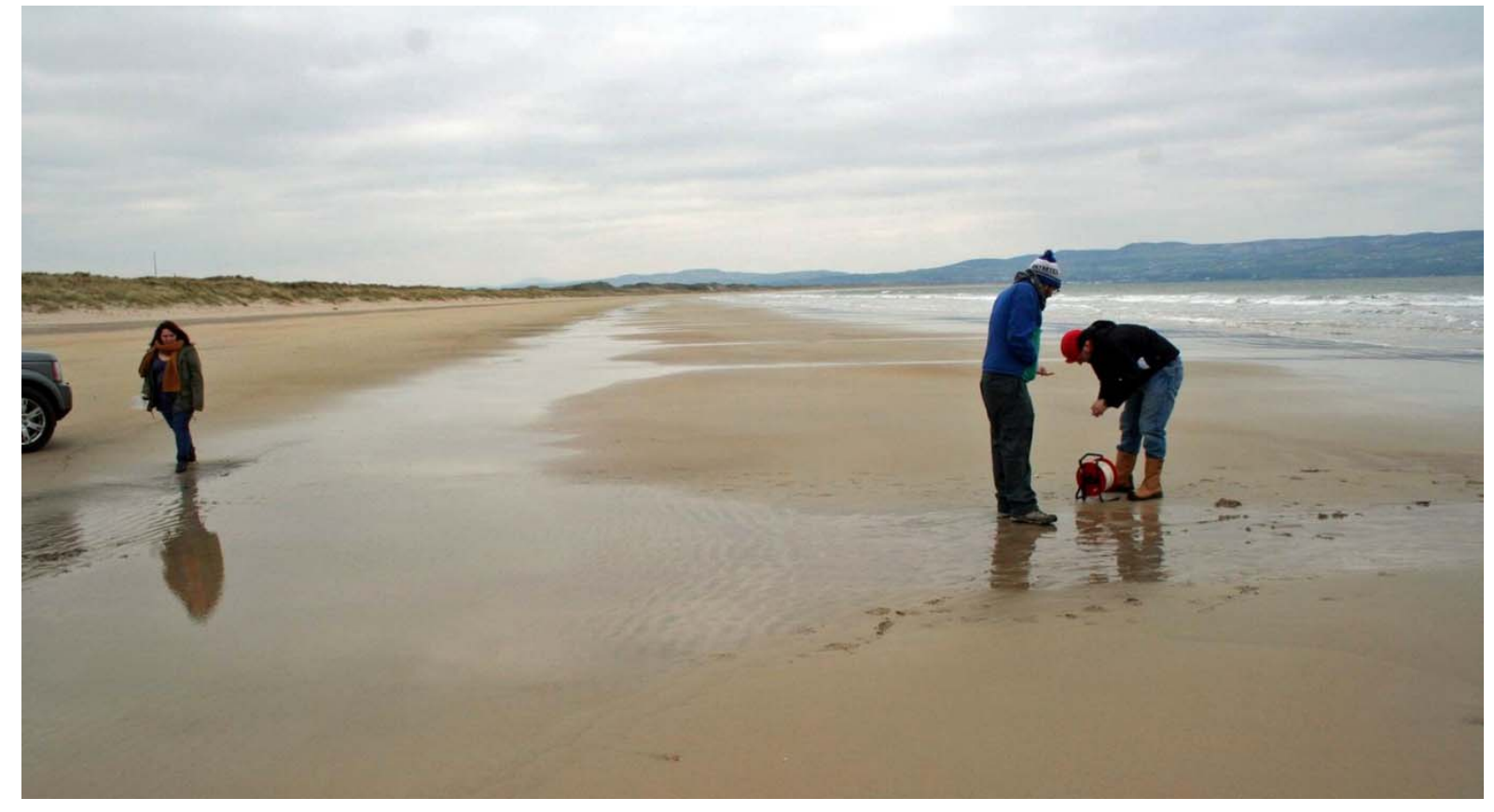

6. Groundwater discharging from the sand aquifer onto Magillian Strand at low tide. 